\title{
The celebrity kyai and phantoms of the past Tussling with the bounds of Indonesian moralities, realities, and popularities
}

After two weeks of controversy the teen flick Buruan cium gue! (Kiss me quick!, 2004, Findo Purwono) was withdrawn from Indonesian cinemas on 21 August 2004. The film had passed the censors but after its release it had elicited strong protests from the famous dai (preacher), public figure, and businessman Abdullah Gymnastiar. Without actually having seen the film - basing his views simply on its title - AA Gym believed that it would encourage illicit premarital sex amongst teenagers. It did not take him long to round up support in Islamic governmental and mass organizations. After two weeks of loud protests from these groups the film was banned from cinemas. The producer, Raam Punjabi, retracted it so as 'not to destabilize the nation any further'.

Muslim protests stirred up by putatively inappropriate films were nothing new. Both under New Order rule and during Reformasi, films were banned, withdrawn from circulation, not publicly screened, or even not produced in anticipation of Muslim protests. Nevertheless, there were subtle changes in the socio-political environment under the New Order compared to after Soeharto's rule had ended. One significant difference was that during Reformasi, in response to the rise of freedom of expression in all kinds of fields, Muslim protests were expressed more loudly. Furthermore, in the freer atmosphere of Reform, images of Islam gradually achieved greater exposure in the Indonesian media. In the context of protests in the name of Islam, between 2003 and 2007 such outcries particularly attracted substantial media attention. It was not just film which elicited protests; music and dance performances and visual arts also drew the ire from some Muslim groups. In 2003 the uproar around Buruan cium gue! was preceded by a controversy about the famous dangdut singer and dancer Inul Daratista. Pious Islamic veteran dangdut singer and film star Rhoma Irama expressed his

(C) Katinka van Heeren, 2012 | DOI 10.1163/9789004253476 008

This is an open access chapter distributed under the terms of the Creative Commons

Attribution-Noncommercial-NonDerivative 3.0 Unported (CC-BY-NC-ND 3.0) License. 
disgust with Inul's sexy dance movements. His objections to Inul's dances launched a heated debate about whether or not her provocative hip rotations could be defined as an act of pornography and be forbidden on the grounds of religious moral values. In 2005 another two cases which attracted ample media attention involved the militant Islamic organization Front Pembela Islam (FPI, Islamic Defenders Front). Like some other Indonesian Islamic paramilitary organizations, FPI can be linked to politicians or high-ranking members of the military and police. ${ }^{1}$ Since its formation in August 1998, FPI had invariably been depicted in the Indonesian media as a fanatical Muslim group which would not shy away from violence to make its point. The first case which involved a protest from FPI in 2005 concerned the use of the Arabic calligraphic symbol for 'Allah' on the cover of the album Laskar cinta (Love army) of the rock band Dewa 19. FPI also objected to a television performance by the band because during the show, dancers trod on the calligraphic symbol which was painted on the studio floor. FPI accused Dewa 19 of blasphemy, reported the band to the Jakarta city police, and demanded a public apology. The second case which made the limelight was accompanied by FPI protests against a photograph on display at the 2005 CP Biennale art exhibition in Jakarta. It depicted a nude Adam and Eve. FPI repudiated this photograph on the grounds that it was pornographic and consequently reported photographer Davy Linggar, art curator of the Biennale Agus Suwage, as well as 'Adam', who was personified by popular television actor

1 Hefner 2002:14, 16. The FPI was formed in August 1998 and has strong ties with high-ranking members of the military and police. It was established with the direct assistance of the then commander of the armed forces, Wiranto (Hefner 2004:14), and now claims to have branches in 22 provinces. Based in Jakarta, FPI is led by Habib Muhammad Riziek Syihab, a religious teacher who was educated in Saudi Arabia. Many of the top FPI leaders, including Habib, have Arab blood. The stated goal of FPI is the full implementation of Islamic Syariah law, although it supports the current Indonesian constitution and avoids making demands for an Islamic state. FPI has a paramilitary wing called Laskar Pembela Islam (Army of Defenders of Islam), and is well known for organizing raids on bars, massage parlours, and gaming halls. FPI justifies these raids on the grounds that the police are unable to uphold the laws on gambling and prostitution. Sceptical observers suspect that the police turn a blind eye to, or are even complicit in, these activities, in the understanding that the victims will be encouraged to keep up payment of protection money to the police. In late 2001, FPI took the lead in threatening to evict Americans from Indonesia in retaliation for the US operations in Afghanistan, although the threat was not actually carried out; see http://www.aph.gov.au/library/intguide/FAD/sea.htm (accessed 19-11-2011). Even though FPI is sponsored by members of the military and police, the faction keeps a certain amount of autonomy. As Robert Hefner emphasizes, FPI cannot be seen as a mere puppet of an all-powerful military. There are significant groupings among the army, police, and the intelligence community who would be happy to see FPI suppressed. Since FPI is aware of the factions and divisions within the army and police itself, it can play this card to resist commands and achieve its own objectives (Hefner 2004:17). 
Anjasmara, and 'Eve', the well-known model Isabella, to the Jakarta police. In February 2006, the four were named suspects who allegedly had displayed obscene art which affronted certain religious groups (Suryana 2006).

The growth in Muslim protests against films, music performances, and works of art in post-Soeharto Indonesia was linked to discourses about the position of Islam in the Indonesian public sphere and its role in the politics of Reform. This issue was a very old one, dating back to pre-Independence days. Then the discourses centred on the position of Islam in the Indonesian Constitution. The burning question at the time was whether the new Indonesian nation-state should separate state and religion or, alternatively, adopt a document known as the Jakarta Charter (Piagam Jakarta). This charter paved the way for the state to implement Islamic law among Muslims. The Jakarta Charter was rejected and in its stead the Pancasila was adopted as the state ideology on 22 June 1945. Reformasi and the concomitant bid it brought to change society reopened the debate on whether the Indonesian nation should be ruled on the basis of Islamic principles. Although in the period between 1998 and 2007 the general feeling was still that Islam should not be part of the Indonesian Constitution, in the public sphere and in regional politics Islamic values were gradually gaining ground. In particular, the law on regional autonomy, officially promulgated on 1 January 2001, strengthened the position of Islamic rule as part of regional regulations (peraturan daerah, Perda). ${ }^{2}$ Between 2001 and 2005, the regional governments in Aceh, Tangerang, Cianjur, Padang, and South Sulawesi all implemented regulations based on Islamic law. Furthermore, in 2006 an important debate took place which involved questions about the position of Islam in ruling the nation. The majority of these discourses occurred in the context of the proposal for the drafting of a new law which would regulate public morality and boost the endeavour to ban pornography from the public domain. Under the presidency of Habibie (1998-1999), rightwing Muslim parties had proposed a new law on pornography. In 2006 their efforts bore fruit in the Rancangan Undang Undang Anti Pornografi dan Pornoaksi (RUU APP, Anti-Pornography and Porno Action Bill). Among the aims the law hoped to achieve, was to ban kissing in public, sensual dances, and the depiction of sexual activity in literature, paintings, photographs, and recordings. ${ }^{3}$

2 For more on regional autonomy, see Usman 2001; Jacobsen 2003.

3 Suryana 2006. For more background information on RUU APP, see 'Anti-Pornography Law- Indonesia' from journeymanpictures, posted on YouTube, http://www.youtube.com/ watch?v=WFm2Y7CmoEA (accessed 19-12-2011). 
Ideas about the implementation of Islamic values in the framework of the bill led to vehement protests from both non-Islamic and moderate Islamic groups. In the words of Muhamad Ali (2006), lecturer at the State Islamic University in Jakarta, the controversy between the proponents of the bill and its critics exposed 'the fault lines of a cultural war between the conservatives and the liberals, with the silent majority in the middle'. Next to the wider exposure and increased intensity of Muslim protests against films, performances, and visual arts, another difference between New Order Indonesia and Reform was that Islamic features became more frequent in audio-visual media after the fall of President Soeharto. To some extent this could be attributed to the growing number of Islamic groups and organizations which had begun to use audio-visual media as a tool for religious propagation and self-representation. As discussed in Chapter 4, this had led to the founding of the new film genre and movement of film Islami. The ideas and representations of Islam which the Islamic film movement had in mind with film Islami did not reach the Indonesian mass media. Instead, as discussed in Chapter 5, horror reality shows produced by commercial television stations were increasingly associated with religious propagation. In 2004, this trend of Islamic authority figures appearing on television increased yet again. A new television genre, called 'religious soaps' (sinetron religius), emerged. Although initially confined to the fasting month of Ramadan, these soaps, which had an outwardly Islamic appearance, were also screened on television after this time. Gradually, images of Islam managed to evade this framework, but the new religious series were still haunted by ghosts and, generally speaking, the stories still focused heavily on tearful repentance. As was the case in the horror reality shows, the religious soaps were imbued with elements of mystery, in the form of supernatural occurrences, and also reiterated the claim that they were based on true stories. Moreover, the religious soaps accorded a major role to heroes in the form of Islamic authority figures, as did films and series of the horror genre. Kyai, ustaz, ulama, or dai appeared in the soaps themselves, or celebrity kyai introduced the programmes and brought them to a close. Hence, even though Islamic films had broken free from the framework of Ramadan, most Islamic productions on television were a far cry from the envisaged film Islami.

The proliferation of images of Islam on television and the wider exposure of Islamic groups in their efforts to regulate audio-visual media, music, and art, could not but influence narrative practices in film and television. This chapter is an attempt to discover the way in which Islam was implicated in defining the bounds of postSoeharto film and television narratives. 
THE BAN ON KISS ME QUICK!: THE KYAI, THE FOREIGNER, AND INDONESIA'S MORALITY

On 5 August 2004, the film Buruan cium gue! was released in top-end cinemas of the Cinema 21 group in fifteen different cities. The film followed the average formula of 'ABG' (Anak Baru Gedhe; teenager) television soaps. It featured a simple love story about a young couple, Ardi and Desi, who are each other's first love. The girl, Desi, comes from a rich family. The boy, Ardi, is a poor orphan who works hard after school to pay for his education. Even though they have been dating for two years, Ardi has never kissed Desi on her lips. Ardi, who adheres to 'old-fashioned' principles, does not want to kiss his girlfriend before it is the right time to do so. Desi, on the other hand, dreams of being kissed by him. Most of her girlfriends at school have already been kissed. On a radio programme about 'the first kiss', Desi lies about her first kiss and it is this lie that stirs up a tempest of troubles. Because Ardi has never kissed her he wonders when and by whom Desi was kissed. After a plethora of misunderstandings all the problems are solved. In the end Ardi and Desi enjoy their first kiss.

Buruan cium gue! was produced by the 'king' of television soaps, Raam Punjabi. Since the beginning of the 1990s his production house Multivision Plus has been very successful in producing popular entertainment for Indonesian television. The film Buruan cium gue! strongly resembled the formula of Punjabi's other soaps, and it also featured actors and actresses who had played in one of his popular soaps, Anak Baru Gedhe (Teenagers). This soap had been launched two years earlier on the Indonesian private television station RCTI. In an interview, Punjabi mentioned that he had wanted to produce a version of the television series for the big screen, because '[t]here are things which actually do happen amongst teenagers but which cannot be shown in soaps; these are exposed in Buruan cium gue!. ${ }^{4}$ Only three days after its release the film sparked major controversy. On 8 August 2004, the then very popular dai Abdullah Gymnastiar raised objections to the film. He did so in his bimonthly Sunday sermon, which was broadcast live from the Istiqlal Mosque in Jakarta on private television channel SCTV, in a homily called Indahnya kebersamaan (The beauty of togetherness).

AA Gym was convinced that the film Buruan cium gue! contained pornographic elements, a conclusion which he extrapolated from its title alone; this inspired him to attack the film in his sermon. He said

4 'Ada hal-hal yang sebenarnya terjadi di kalangan remaja tapi tidak bisa ditampilkan dalam sinetron, itulah yang dimunculkan dalam Buruan Cium Gue!' ('Sekadar menjadi versi bioskopnya', Kompas, 8-8-2004.) 
Buruan cium gue! was dangerous, as it would encourage premarital sex among teenagers. Gym said that according to Islamic doctrine it was a sin for a man and a woman who were not married even to touch each other, let alone kiss. Not only did such a kiss run counter to Islamic doctrine, it was one sure step on the road to premarital sex. Pursuing this theme, AA Gym asserted that the title of the film might as well be changed to Buruan berzinah (Hurry up, let's fornicate).

Soon after his televised sermon, AA Gym won the support from the MUI and several Islamic mass organizations. Some of these mass organizations initiated protests against the film, demanding that it be banned. The president of MUI, Amidhan, asserted that the film was not at all suitable to be screened in Indonesia. He too considered the title of the film to be an insuperable hurdle. It implied 'porno action' ( porno aksi, meaning porn-related acts). Moreover, he believed that scenes of premarital kissing in the film destroyed the morality of the nation and should therefore be banned. Amidhan argued that additionally the film could be construed as an insult to religion. He felt personally offended that the film portrays the tale of how an initially deeply pious boy discards his religious moral values and in the end succumbs to kissing his girlfriend before marrying her (Yordenaya 2004a). Presumably stimulated by the support of MUI and the mass organizations, AA Gym began a tour around the city in efforts to gauge the popularity of Buruan cium gue! among film audiences. On Friday 13 August, in an interview before his visit to some film theatres, he laid heavy emphasis on the fact that he did not intend to watch the film personally. He reiterated that the title alone made it palpably clear that it ran counter to basic religious values and posed a serious danger to the younger generation of Indonesians. AA Gym declared that his sole purpose was to visit the cinemas to check on the popularity of the film. Precisely because of the controversy he had stirred up, the cinemas which screened Buruan cium gue! were packed. Many in the audience simply wanted to see what all the fuss was about and were curious about the risqué scenes. The majority came away disappointed after watching the film. It was an ordinary Indonesian soap or teen flick and there was nothing special to see. ${ }^{5}$

5 For example, in the wake of the controversy the ticket sales in Semarang rose. About $70 \%$ to $80 \%$ of the tickets were sold, which was not often the case when Indonesian films were screened. At first the pro-contra issue about Buruan cium gue! brought in lucrative business. However, when it became known that the film did not touch on any particularly controversial matters, ticket sales soon declined. See 'Mana yang perlu disensor?', Minggu Pagi Online, http://www.minggupagi.com (accessed 28-8-2004). 
Nevertheless, AA Gym and his supporters continued their mission of protest against the film. Five days after his cinema visits, AA Gym and his associates set out to call on LSF. On 18 August they paid a visit to the head of the institute, Titie Said, in order to interrogate her about the institute allowing the film's general circulation in cinemas. In answer to Gym's questions, Titie Said explained that the kissing scene in Buruan cium gue! adhered to the censor's guidelines. It was believed that the scene portrayed a part of the daily lived reality of contemporary Indonesian youth. Moreover, Titie argued, before the making of Buruan cium gue! several other Indonesian films which had passed the censor had already contained kissing scenes. She explained that the title reproduced the trendy language used among teenagers. Despite her neutral explanation, after the visit by AA Gym, Titie Said commented in an interview that she believed that Gym's call on LSF was a sign that the institute had made an incorrect decision. As the film had already passed the censorship procedures, however, the institute was not entitled to withdraw it from cinemas (Yordenaya 2004b).

Surprisingly, four days later it was. On 21 August 2004, after a fortnight of controversy, the film was withdrawn from the cinemas. The institute, with the agreement of Punjabi's Multivision Plus, had decided to bow to the pressure of the public rejection of the film. LSF withdrew its approval of the film on the grounds that it had 'disrupted public order'. The Ministry of Culture and Tourism issued a letter revoking the distribution of the film and Multivision asked cinemas to stop screening it (Unidjaja 2004). The film copies were sent back to the production company, and it was decided that Buruan cium gue! would be re-released later that year after some editing and under another title. Raam Punjabi told the press that in revising the film, he would involve religious leaders in the production process in addition to the censor institute. Punjabi regretted that Buruan cium gue! had been banned, but believed that it was more important that the nation was not divided over it. ${ }^{6}$ Punjabi clearly emphasized he had not retracted his film because of its content. The film, he argued, showed nothing but the factual lives of middle-class young people in Indonesian society.

The controversy did not stop there. In their turn groups of journalists, intellectuals, film-makers, writers, artists, and other public figures began to protest the banning of the film. The protest raised by these groups articulated a fear of the implementation of a new form of censorship on the basis of religious moral grounds. In the

6 'Mana yang perlu disensor?', Minggu Pagi Online, http://www.minggupagi.com (accessed 28-8-2004). 
newspaper The Jakarta Post, cultural critic Zoso wrote that he was afraid that censorship on the basis of religion would be the first step on the path to political repression and restrictions on the freedom of expression. He recalled that the Indonesian media had already experienced such restrictions under Soeharto rule and nobody wanted to go back to this. Zoso (2004) emphasized that religion should not become an instrument of harassment. Others also probed the question of the role of religious pressure in the banning of Buruan cium gue!. ${ }^{7}$ On 25 August the cultural centre Utan Kayu produced a petition signed by film-makers, intellectuals, artists, and other public figures. This petition addressed three points. Its first point was that the withdrawal of the film was an annihilation of the freedom of expression and could be seen as an anti-democratic action at odds with human rights. Its second objection was that religious authorities and symbols (in this case Islamic) should not be brought into the public sphere, but be reserved for the private sphere. The third objection raised was that this ban on a work of art was perceived as moralistic, dogmatic, old-fashioned, and not representative of the religious/Islamic community in Indonesia as a whole (Gaban 2004).

Ignoring such criticisms, Islamic pressure groups continued to stage protests against films and television programmes. Members of the Aliansi Masyarakat Anti Porno-Aksi (AMAP, Alliance of People against Pornographic Acts) complained about the programmes Cowok cowok keren (Handsome guys) on RCTI, Nah ini dia (Nah here he/she/it is) on SCTV, and Layar tancep (Mobile cinema) on Lativi. In their view, these programmes were merely a vehicle for selling sex. Even though each of the series had passed the censor, as far as AMAP was concerned they exceeded the boundaries of what was acceptable in the Indonesian media. ${ }^{8}$ In this atmosphere, producers of films which might possibly elicit protests tried to pre-empt objections, usually by claiming that their films just represented reality. One of these films was Virgin (Hanny Saputra, 2004), which was released not long after Buruan cium gue! The film, which was noticeably inspired by the US films Thirteen (Catherine Hardwick, 2003) and Coyote ugly (David McNally, 2000), was said to depict daily life

7 Film director Ahmad Yusuf believed that AA Gym should have watched BCG! first before voicing his protests. The fact that the film was removed from cinemas after AA Gym's protests, he stated, recalled the atmosphere of the old regime. He considered the role of MUI to also be dubious, as the MUI member on the Censor Board had obviously let the film pass for release. Still, after AA Gym had raised an outcry, MUI had joined the protests against the film. 'Mana yang perlu disensor?', Minggu Pagi Online, http://www.minggupagi.com (accessed 28-8-2004).

8 'Mana yang perlu disensor?', Minggu Pagi Online, http://www.minggupagi.com (accessed 28-8-2004) 
in contemporary Indonesia. In a television programme about the making of Virgin, producer Chand Parwez emphasized that the film showed what was actually happening in Indonesian society. According to Parwez, Virgin, which depicts teenage girls clubbing, using drugs, drinking alcohol, and selling their bodies to men to pay for trendy clothes and gadgets, was produced 'to inform and warn parents'. Parents, he said, should watch the film together with their children in order to make themselves aware of the dangers inherent in contemporary city life and, thus armed, teach the children right from wrong.

At the same time as protests about the moral value of Buruan cium gue! and similar films were occuring, an anti-pornography law was being drafted. ${ }^{9}$ In 2006 discussion of the bill led to a huge controversy, which, according to lecturer Muhammad Ali (2006), was best understood in the context of the struggle of finding a fitting definition of the public morality of the Indonesian nation-state. Until 2006 any serious discussion of the law had mainly been conspicuous by its absence. The law was proposed under the presidency of Habibie and was brought up again a few times during the presidencies of Abdurrahman Wahid and Megawati Soekarnoputri. In 2003, new interest in an anti-pornography law was aroused by the enormous upheaval across the country caused by the erotic dance movements of the dangdut singer Inul Daratista. The hip gyrations of the rising star were compared to the working of a drill, giving her the title 'queen of the drill dance' (ratu ngebor). Inul's dance aroused the ire of celebrity, film star, and 'king of dangdut' Rhoma Irama. A devout Muslim, Rhoma Irama declared that Inul's drill dance posed a threat to the morality of the country and that such 'porno-action' - he was the one who launched the term - should be banned from the public domain. The row between Inul and Rhoma Irama received wide exposure in the Indonesian mass media and divided Indonesia into pro- and contra-Inul camps (Barendregt 2006; Wiwik Sushartami forthcoming). It did not take long for the controversy to enter the forum of social and political discourse and instigate discussions on public morality. Some were captivated by Inul's dance movements and viewed these as a form of art. Others were loud in their condemnation, as they believed Inul's dance movements downgraded the nation's morality. The discourses on Inul's drill dance as an expression of porno-action prompted some right-wing Islamic groups in the House of Representatives to

9 See the revealing title of an article in The Jakarta Post of 21 August 2004: 'Local teen flick withdrawn after Muslim leaders' protest; The House of Representatives is deliberating a bill on public morality, which bans kissing in public'. 
push for the speedy enforcement of a law against pornography and porno-action. However, it was to be another two years before the Anti-Pornography Bill was discussed intensively. ${ }^{10}$

The case of Buruan cium gue! widened the scope of earlier discussions about the role of the government and Islamic values in the regulation of public morality. In an article posted on the Indonesian mailing list Layarkata, Farid Gaban, a journalist at Kantor Berita Pena Indonesia, wrote that the protests against Buruan cium gue! went far beyond this film. Farid interpreted these as a symptom of the Indonesian public being fed up with the existing trend in Indonesian mass media, which were completely dominated by mystery programmes, an obsession with private lives and the scandals surrounding celebrities, and vulgar criminal news programmes (Gaban 2004). In the same vein, in 2005, commenting on the controversy around the Anti-Pornography Bill, Muhammad Ali suggested that the drafters and supporters of the bill thought that the moral values in Indonesian society were being degraded by the rise of freedom of expression. Thinking particularly of the increase in pornographic materials in tabloids, art shows, literature, and films, Ali argued that such people saw these developments as a massive threat. Religious leaders and pressure groups, Ali believed, needed the bill as they found themselves powerless to impose their worldviews without a legal basis (Ali 2006). ${ }^{11}$

While some believed that freedom of expression had gone too far and blemished the Indonesian nation, others embraced it as part of the open and democratic society Indonesia had become during Reform. As mentioned earlier, some feared that religion would provide the new grounds on the basis of which the freedom of expression in Indonesian society would be restricted. Such commentators as Zoso (2004) compared the role of AA Gym and Islamic groups which had elicited the ban of Buruan cium gue! with 'the tyrannical authority' exercised by the Department of Information during the New Order. Gaban likewise expressed the fear that the case of Buruan cium gue! would lead to a new renunciation of freedom of expression. He was worried that the petition launched by Utan Kayu would trigger a polarization in which AA Gym would be supported by such groups as FPI, the Majelis Mujahiddin Indonesia, (MMI, the Indonesian Council of Defenders of the [Islamic]

10 In early 2005, President Susilo Bambang Yudhoyono declared he would call for maximum measures to ban pornography in Indonesian written and audio-visual media (Barendregt 2006:9-10).

11 In his paper on the use of mobile phones and debates on the RUU APP, Barendregt (2006:6) also refers to the fear of some that the liberalization of society had gone too far. 
Faith), components of the Hizbut Tahrir (HT, Party of Liberation, an international Sunni pan-Islamist political party), or the Partai Keadilan Sejahtera (PKS, Prosperous Justice Party), which would fight with renewed vigour. Gaban (2004) was afraid that if that happened, the government would respond by reducing freedom of expression drastically.

Nevertheless, in the views of some others, among them noted psychologist Sartono Mukadis, comparing the ban on Buruan cium gue! to the limitations imposed on the freedom of expression during the New Order was inaccurate. Mukadis was adamant that the protests of one person backed by a number of groups could not be compared to the rigid control exercised by institutions which was implemented under the New Order. He was not at all convinced that the case of Buruan cium gue! reflected the birth of a new system which would curb the freedom of expression on the basis of religion because, he argued, when Rhoma Irama spoke on behalf of religion in his attempts to stop Inul from performing, he had failed to achieve his purpose (Mukadis 2004). In a similar comparison, Jujur Prananto went a step further. He did not think the cases of Buruan cium gue! or Inul were connected to the question of whether Islam was at the basis of new censorship regulation in Indonesia. Instead, he saw both cases as evidence that control over the nation was in the hands of those people who wielded great influence. In the era of Reform, Prananto argued, power was in the hands of the most popular celebrities: at the time, Inul Daratista and AA Gym (Prananto 2004). Even so, Inul owed her victory over Rhoma Irama not only to her popularity, but also to the fact that she was supported by prominent Nahdlatul Ulama (NU, Revival/Awakening of Islamic Scholars, a 30-million-strong Muslim organization) figures such as former Indonesian president Abdurrahman Wahid and Ahmad Mustofa Bisri (Islamic leader and teacher as well as painter and poet, well known as Gus Mus).

Prananto did address two valid points. Firstly, it was true that in post-Soeharto Indonesia celebrities dominated the mass media and, secondly, that the use of religion as grounds to control censorship was not irrefutable. The victory of AA Gym and religious groups in the case of Buruan cium gue! was based not purely on religion. It was a mixture of stardom, popularity, and religion, all on the side of the popular real-life kyai-celebrity AA Gym, which turned the case into a non-contest for Raam Punjabi, the film's producer. The latter was of Indian descent and therefore open to accusations of being a 'foreigner' and 'capitalist' promoting non-Indonesian secular realities. As said, the withdrawal of a film in response to Muslim protests was not something new. Under the New Order 
there had also been some cases in which Islam was used as grounds to ban or retract films. The next section gives a broader overview of the role of Islamic authorities and mass organizations and the fear of Muslim protests in film production, exhibition, censorship, and self-censorship during the New Order and Reform.

\section{CENSORSHIP FROM THE STREET: THE AUTHORITY OF RELIGION}

Under the New Order, influential censorship of the media was based on the principle of SARA. The mass media were not permitted to cover SARA-related subjects in any critical way, as there was a fear that this would destabilize the nation. Besides the guidelines for SARA, rules and regulations were drawn up specifically for film administered by the Film Censor Board/Institute (BSF/LSF.) The members consisted of representatives of the government, the legal profession, the army, film producers, and several religious organizations, among them the Indonesian Ulama Council, Nahdlatul Ulama, Muhammadiyah, Dewan Gereja-Gereja di Indonesia (DGI, Council of Churches in Indonesia), Konferensi Wali Gereja Indonesia (KWI, Bishops' Conference of Indonesia), and Parisada Hindu Dharma Indonesia (PHDI, Hinduism Society) ${ }^{12}$ Both domestic films and imported products had to pass the board of censors before they could be released in cinemas or on television, or distributed in the format of video cassettes, VCD, and DVD. As mentioned in chapters 2 and 5 , besides the official censorship regulations laid down in Indonesian film legislation, a special Ethical Code for Film Production was created in 1981. Despite the involvement of a special commission for administering religious principles in the creation of the Ethical Code for Film Production and the co-operation of representatives of religious mass organizations in the censorship system, from time to time there were protests about films, which were led by religious, mainly Islamic, communities and (mass) organizations. These protests interfered directly in censorship proceedings, or were raised to demand the withdrawal of films which had already been released by the board. However, such protests were apparently random: not all films which might conceivably have been rejected on the grounds of religious sentiments raised objections, and at times protests were elicited by films which contained nothing that could be construed as contrary to religious teachings. 
Between 1993 and 1997, such groups as Forum Komunikasi Lembaga Dakwah, (FKLD, Communication Forum of Dakwah Institutions), Himpunan Mahasiswa Islam (HMI, Association of Islamic Students), Komite Indonesia untuk Solidaritas Dunia Islam (KISDI, Indonesian Committee for Solidarity in the Islamic World), and branches of MUI in different provinces of Indonesia all lodged protests about films. ${ }^{13}$ The greatest objections were raised against 'pornographic' images in Indonesian films. Ever since the 1970s, various Indonesian films had toyed with an impression of female nudity and sex. Members of Muslim organizations in particular feared that these films would have a bad influence on the young generation and lead them to stray from religion. The films were deemed to be unacceptable from the point of view of religion and to oppose the essence of Indonesian cultures and traditions. Anwar Sanusi of Lembaga Pengkajian dan Pengembangan Dakwah (LPPD, Institute for the Study and Development of Dakwah) and Ahmad Suaidy and Husein Umar, respectively head of and spokesperson for FKLD, argued that Indonesia was a pious nation. ${ }^{14}$ Even though the majority of those protesting about films were members of Muslim groups, leaders of other religious groups upheld the same ideas about pornography. They also argued that films which contained nudity or sex should be forbidden: 'The sentiments of the Islamic community are also those of the Roman Catholic, Protestant, Hindu and Buddhist communities' ${ }^{15}$

Alongside regular protests about the circulation of both legal and illegal pornographic films and videos, or the qualms voiced about sexy film posters, which mainly tended to be lodged during the fasting month of Ramadan, under the New Order there were three particular cases in which protests about films sparked heated controversy. ${ }^{16}$ In all three cases, Muslim protests interfered in the work of the film censor. Twice the controversy involved imported

13 '12 lembaga dakwah protes keras film "Bagi-bagi Dong", Pelita, 31-12-1993; 'Kelompok Islam di Yogya protes film porno', Pikiran Rakyat, 2-8-1994; 'MUI Jatim minta sensor film dan iklan TV diperketat', Berita Yudha, 28-7-1995; 'MUI Jatim minta film \& iklan jorok dilarang', Berita Buana, 26-1-1996; 'Ulama Jatim protes tayangan sadisme di TV', Republika, 4-3-1996; Yaya Sutara 1994.

14 '12 lembaga dakwah protes keras film "Bagi-bagi dong”, Pelita, 31-12-1993; “"Bagi-bagi dong” diprotes 58 ormas Islam', Harian Terbit, 7-1-1994; Anwar Sanusi 1993.

15 'Tindak tegas distributor', Suara Karya, 21-7-1996.

16 For accounts of various protests, see 'Umat Islam Jabar; Habisi film porno', Republika, 25-71994; 'Kelompok Islam di Yogya protes film porno', Pikiran Rakyat, 2-8-1994; 'Puluhan ormas Islam protes film porno', Merdeka, 2-8-1994; 'Keberatan pemutaran film porno; HMI Ciamis datangi DPRD', Pelita, 17-2-1995; 'Ketua LPLI Sunan Ampel; Hentikan film panas selama bulan puasa', Sinar Pagi, 18-1-1996; 'MUI Jatim minta film \& iklan jorok dilarang', Berita Buana, 26-11996; 'Di bulan Ramadhan poster porno masih marak', Berita Yudha, 28-1-1997. 
films from the US. The first of these was True lies (James Cameron, 1994), which was perceived to be an insult to Muslims as they were represented as terrorists. Even though True lies had passed the censor, Muslim groups demanded it to be withdrawn from circulation. The upshot was that its popularity soared and it was transformed into an item very much in demand in pirated-video sales. The second film which upset Muslim sensibilities was Schindler's list (Steven Spielberg, 1993), which never reached Indonesian cinemas. Before they had even watched the film, some Muslim groups were convinced that it contained Jewish propaganda and protested against its release in Indonesia. In order not to incite Muslim protests further, but also because it did not get permission from the film-maker to cut any scenes, LSF decided not to release the film. ${ }^{17}$ Again this film proved a popular item which was widely available in piracy networks. A third controversial case involving the efforts of Muslim groups to override state censorship. was sparked by the Indonesian film production Pembalasan Ratu Laut Selatan (Revenge of the Queen of the Southern Sea, Tjut Djalil, 1988). This film was a horror story about a legendary goddess who harbours a snake in her vagina which bites off the vital organs of men who have sex with her. Pembalasan Ratu Laut Selatan had passed the censor, but after its release Islamic organizations strongly objected to the film's content. The organizations objected to the pornographic theme of the film and singled out particular scenes for especially hard criticism. Because of the uproar caused by these protests, after a few days the film was withdrawn from cinemas.

During and after Reformasi a huge wave of new developments in the world of film came about. Just as various groups and film-makers were experimenting with testing the boundaries of Reformation's new freedom of expression, some Islamic groups were gauging the extent to which they could have their say in the restriction of these liberties. ${ }^{18}$ Such Islamic groups as FPI, PKS, and the laskar (paramilitary unit) of Masyarakat Anti Pembajakan dan Pornografi Indonesia (MAPPI, Indonesian People Against Piracy and Pornography), a special force consisting of some 750 people, the majority of whom were part of the banser (paramilitary wing) of NU, organized themselves to win victories over what they considered amoral, anti-Islamic film products. MAPPI instigated raids to halt the sell-

17 'Schindler's List \& sensor kita', Pikiran Rakyat, 10-7-1994.

18 These discourses recall the early years of Independence in the 1950s. At that time debates were also imbued with a spirit of great enthusiasm about the future of Indonesian cinema and also covered the questions of American film imports, censorship, and Islamic morality (Sen 1994:19-20, 22-3). 
ing of pirated or banned films, which involved demolishing stalls of street vendors. ${ }^{19}$ FPI mainly confined itself to threats. Television stations and organizers of film festivals, for example, were left in no doubt that their offices or cinemas would no longer be safe if the screening of certain films was to go ahead. ${ }^{20}$

In post-Soeharto Indonesia, the fear of protests from Islamic groups not only restricted the distribution of films, but at times also hindered the production process. In 2001 film director Garin Nugroho planned to make a film, called Izinkan aku menciummu sekali saja (Let me kiss you just once), about a young boy in a pesantren, who dreams of kissing a beautiful Chinese girl whom he happens to see walking by every day. However, after protests from pesantren representatives the producer retracted funding for the production of the film (Wardhana 2001b). Garin relocated the setting to Papua, where Roman Catholics are in the majority. In 2003 the film was released under the title Aku ingin menciummu sekali saja (I want to kiss you just once). ${ }^{21}$ Garin Nugroho found himself contending not only with protests from Muslim groups. In 2005, during the pre-production of his film Sinta obong (The burning of Sinta), the Gerakan Perempuan Hindu Muda Indonesia (GPHMI, Indonesian Young Hindu Women's Movement) repudiated the film because it believed the screenplay was offensive to the Goddess Sinta and the true story of the Ramayana. GPHMI also emphasized that even though Hinduism was a minority religion in Indonesia, the nation should be aware that one billion Hindus worldwide believed in the Ramayana. Moreover, they declared, Bali, Hinduism, and its symbols and sacred books should neither be attacked by bombs (referring to terrorist attacks that were committed in the name of Islam

19 'Laskar MAPPI siap menggeledah Glodok', Media Indonesia, 16-4-2000.

20 In 1999, violent threats by FPI to disrupt the screening of the Israeli film Kadosh (Sacred, Amos Gitai, 1999) caused the committee of the Jakarta International Film Festival not to show it. In 2000, protests by FPI led to the end of the screening of the highly popular Latin-American soap Esmeralda on SCTV. FPI demanded that the soap be banned because the antagonist was called Fatima, the name of the daughter of the Prophet Muhammad, and giving an antagonist her name was perceived to be an insult to Islam. In 2003, members of PKS organized protests in all cities during the road-show of the independent film production Novel tanpa huruf $R$ (Novel without the letter R, Aria Kusumadewa, 2003). However, the film-maker refused to stop screening his film and in a counter-move opened a debate with the people who had protested against his film at a film screening in Bandung.

21 In the same year, Garin Nugroho encountered another protest from Islamic groups. This time the trouble was caused by his production of a Public Service Announcement (PSA) called Islam warna warni (Different hues of Islam). The MUI protested against this PSA and demanded a ban, alleging that mentioning the 'different hues' of Islam represented Islam as something ambiguous. In the opinion of MUI, there was only one Islam, and different interpretations of the religion were not possible. To represent Islam as something unfixed was perceived as an insult (Abidin 2003). 
in 2002 and 2005), nor treated with contempt (pelecehan).$^{22}$ In the end Garin produced the film after judiciously changing the title to the more comprehensive Opera Jawa (Javanese opera, 2006).

In addition to these examples, generally speaking between 1999 and 2004 the religious protests, the majority of which were launched by Muslim groups, were not markedly different from those staged under the New Order. In the outcry concerning film and VCD and DVD productions most protests targeted 'amoral' films depicting what was interpreted as pornography as well as female nudity. On television in particular, Latin-American telenovelas and such American series as Baywatch, Melrose Place, and VIP were considered to be incompatible with Islamic values, which were often cited as forming the basis of Indonesian culture and civilization. As a sop to accommodate members of the Islamic community, programmes which may have been construed as offensive were put on hold during the Islamic fasting month. But as soon as Ramadan was over, they simply resurfaced. ${ }^{23}$ Again, notwithstanding the various examples which may be adduced, it must be emphasized that religious protests about films were sporadic and did not cover all films which might have incited controversy from a religious-moralist point of view. For example, a kissing scene in the teen flick Ada apa dengan Cinta (What's up with Love, Rudi Soedjarwo, 2002), and a kiss by a gay couple in Arisan (Gathering, Nia Dinata, 2003) did not generate a murmur of dissent.

After the ban on Buruan cium gue! and protests against various television programmes by AMAP at the end of August 2004, discourses began to address the need for the involvement of religious authorities in film and television production. Because of the controversy aroused by Buruan cium gue!, both the strengthening of the role and representation of Islamic authority figures in the LSF and a revision of censorship rules in the near future, including the assessment of film titles, was on the cards. ${ }^{24}$ Some favoured the involvement of Islamic authority figures, not as any official part of the state system but in the form of pre-censorship or self-censorship in the production process. In early August 2003, a year before the controversy about Buruan cium gue! erupted, a representative of film professionals in the censor institute, Tatiek Malyati Ws, had already put

22 'Film Sinta Obong diprotes di Bali', Bisnis Indonesia, 9-12-2005.

23 'Libatkan para ulama dalam Badan Sensor Film', Terbit, 18-1-2000; 'MUI; Pemerintah harus tegas tertibkan pornography', Warta Kota, 13-11-2001; '90\% tayangan teve langgar kaidah agama', Republika, 13-3-2002.

24 'Mana yang perlu disensor?', Minggu Pagi Online, http://www.minggupagi.com (accessed 28-8-2004) 
in a request for stronger self-censorship on the part of film producers and television stations. Moreover, she had called on the leaders of the nation, parents, and religious authorities to be pro-active in lodging complaints against pornographic films and participating in censorship..$^{25}$ In the controversy which blew up around Buruan cium gue!, it seems her ideas were implemented. Besides pro-active protests leading to a ban on a film, king of soaps Raam Punjabi announced that he intended to involve religious leaders in the revision of Buruan cium gue!. ${ }^{26}$ It is difficult to obtain any clarification on the ways in which and extent to which Raam Punjabi proceeded in honouring this promise of involving Islamic authorities in his film and television productions. It is remarkable, however, that after the ban on Buruan cium gue!, religious soaps appeared more frequently on television and were no longer confined to the framework of Ramadan.

The boom in the production of religious soaps commenced in February 2004, when the private television station TPI began to broadcast the series Rahasia Ilahi (God's secret). ${ }^{27}$ The series was based on true stories of people who had experienced the wonders of God, accounts of which were published in the magazines Hidayah (God's guidance) and Allah Maha Besar (God is great). Rahasia Ilahi was hosted by Ustaz Arifin Ilham, a young, fairly popular dai. Television viewers loved the series and it brought TPI to the number one spot in the AC Nielsen ratings with a share of $15.8 \%$. Sensing a successful formula, other television stations were quick to follow suit with similar programmes. ${ }^{28}$ While most of the series drew their stories from among the common people, some religious soaps were based on stories from old Islamic sources.

25 'Sensor segera tayangan televisi...!', Republika, 6-8-2003. At the beginning of 2003, when 45 new members of the Film Censor Institute were appointed for the period 2002-2005, the secretary of MUI, Ichwan Sjam, stated that he regretted that the number of representatives of religious mass organizations in the board that year had declined from two persons per organization to only one ('Cyber Media', Kompas, 28-1-2003). Before 2003, the Islamic mass organizations Muhammadiyah and NU were both represented by two persons on the board.

26 'Mana yang perlu disensor?', Minggu Pagi Online, http://www.minggupagi.com (accessed 28-8-2004).

27 For more on the popularity of religious series in for example Egypt and India, see AbuLughod 1993 and Mitra 1993 respectively.

28 SCTV produced Astaghfirullah (May god forgive me!; also an exclamation used when one is shocked by immoral behaviour), based on true stories from the magazines Ghoib (Mysterious, pertaining to the invisible (divine or supernatural) sphere) and Kuasa Ilahi (God's power). Trans TV had Taubat (Repent and foreswear), taking its stories from the magazine Insting (Instinct), and the series Insyaf (Aware) and Hidayah. Lativi screened Azab Ilahi (God's wrath) and Sebuah kesaksian (Witness to faith), both based on stories of people who had experienced or witnessed miracles which they attributed to God. 
These sources, mainly hadits (traditional collection of stories relating to words or deeds of the Prophet Muhammad, the chief source of guidance for understanding religious questions), were adapted to a present-day setting. To name one, TPI's Takdir Ilahi (God's divine decree) used hadits taken from Bukhari and Muslim, which were inserted in the books Mi'ah qishshah wa qishshah $f i$ anis al-shalihin wa samir al-muttaqin (One hundred tales and the tale of the righteous), written by Muhammad Amin Al-Jundi Al Muttaqin, and Madarij al-salikin (The path of the mystic traveler), written by Ibnu Qayyim Al-Jauziah. ${ }^{29}$ In advertisements, TPI went to great lengths to emphasize that Takdir Ilahi was an 'actualization of occurrences which had once taken place in the time of the Messenger of God' (aktualisasi dari peristiwa yang pernah terjadi di zaman Rasulullah) (Ruslani 2005).

The above-mentioned religious television series featured both supernatural occurrences and an Islamic authority figure. A kyai, ustaz, ulama, or dai would appear at the beginning or the end of the episode either to introduce and explain the programme, or to play a role in the story itself. For example, the young ustaz Jeffry al-Buchory, who was very popular among teenagers, hosted the programme Azab Ilahi. Each episode of Astaghfirullah featured an ustaz in its storyline, and the series Takdir Ilahi always ended with pronouncements by Ustaz Ali Mustafa Yaqub from MUI. Mustafa not only explained the hadits on which the series was based to round off the programme, he also supervised every stage of production. To conclude, Mustafa would present a disquisition on the solution by which the evil forces which had exerted a baneful influence on the main character could be exorcised. The director of the series, Chaerul Umam, emphasized that in the series the ustaz used the Islamic ruqyah method, a sanctioned instrument to expel evil, consisting of prayers which are consonant with the Syariah. As most of the religious series either contained elements of mystery or the intrusion of supernatural occurrences, the mission of the authority figures was to link these specifically to religious teachings. The producer of Takdir Ilahi, Dondy Sudjono, and Chaerul Umam explained that the appearance of Islamic authority figures in their series was to ensure that proper information was disseminated about how to deal with the supernatural. Without the explanations provided by Islamic authority figures, people might not interpret the series cor-

29 Bukhari and Muslim were Arab Islamic scholars who lived around AD 800/200 Shawwal. Their books, both called Sahih, are still highly celebrated among the collections of traditions (Gibb and Kramers 1974). 
rectly, and there was the lurking danger that these series would only feed people's superstitions.

In fact, the religious programmes did not differ greatly from regular television horror programmes. Cultural critic Taufiqurrahman (2005) described the contents of the religious series

as regular soap operas with God's name attached to their title [which] carry a formulaic story line in which sinners of all kinds, from corrupt state officials and gamblers to a misbehaving son, will be punished by God with a very painful death, ranging from literally being burnt in hell, eaten by flesh-eating worms to being swallowed alive by the earth. By the drama's end, after a noisy commercial break, a preacher will appear on screen to give a sermon about what sinners will face in the afterlife in return for their misdemeanors and will remind viewers not to commit sinful acts.

Moreover, Taufiqurrahman (2005) pointed out, as time passed some religious soaps deteriorated into campy horror shows featuring 'devout religious leaders [who] become engaged in Armageddon-like battles against demons (portrayed with red skin and two horns on their heads) and ghosts of all kinds'.

Only a few 'Islamic' soaps did not contain elements of mystery or supernatural occurrences. The actor and film producer Deddy Mizwar, who had produced and directed the Islamic film Kiamat sudah dekat (Judgement day is nigh, 2003) and played a role in its soap version, regarded the religion-inspired series as a mere extension of the horror and mystery programmes. In his opinion, the only difference was that these programmes now were packaged as if they were about Islam. The soaps, he argued, actually just repeated the success of mystery films in Indonesian cinema in the 1970s. This was the reason Deddy claimed that 'our nation has now stepped back again to the 1970s' (masyarakat kita sekarang ini mundur ke zaman 1970-an lagi) (Fitrianto 2005). Despite the dubious quality of the majority of religious programmes, MUI embraced them wholeheartedly. In 2005 its secretary general, Din Syamsudin, was quoted by the weekly Gatra as saying that there had been an internal discussion about the possibility of handing out awards to television channels which ran religious series. ${ }^{30}$ Ismail Yusanto, spokesperson of Hizbut Tahrir, also believed that the religious shows breathed a breath of fresh air into TV programming (Taufiqurrahman 2005).

30 Taufiqurrahman 2005. As mentioned in Chapter 4, MUI had given awards in recent years to television stations which contributed to enlivening the Ramadan fasting month. 
THE POST-SOEHARTO DISPUTE OVER CENSORSHIP: SPIRITS OF REFORM AND GHOSTS FROM THE PAST

With the twin phenomena of the growing fear of Muslim protests taking control of the film industry and the rise of religious soaps, it is fair to say that Islam increasingly directed narrative practices of post-Soeharto audio-visual media Along the lines of the earlier controversy about the Anti-Pornography Bill in January 2007, the juxtaposition of religious sentiments supporting conservative forces in society against those defending more liberal views also affected the world of film. At the end of December 2006 a new film movement, Masyarakat Film Indonesia (MFI, Indonesian Film Society) was founded. MFI represented a group of film professionals who wanted to initiate a belated reform of the old power structures in the film industry. It soon found itself in opposition to an old New Order film institution, LSF. In the disagreement between the two, LSF found support in its former opponent, the militant Islamic organization FPI. The commitment of FPI to the censor institute and its opposition to MFI reflected the wider conflict between conservative and liberal forces in the contest to rule the nation, bolstering public allegations that Islamic pressure groups were being put to use in a game of power play manipulated by the state.

The controversy was sparked off by the tremendous upheaval about the awards which were handed out at the Indonesian Film Festival (FFI) at the end of December 2006. After the fall of Soeharto, the production of films had grown because of the rise of mainly independent film-makers. In 2004 the state responded by reviving the Indonesian Film Festival. FFI, which had been held for the last time in 1992, was organized by a committee chosen by the Badan Pertimbangan Perfilman Nasional (BP2N, National Film Assessment Board). Since 1992 the BP2N had been the umbrella organization of all official New Order film organizations. As discussed in chapters 1 and 2, notwithstanding Reform and the dismantling of the Department of Information under the presidency of Abdurrahman Wahid, the New Order organizational system pertaining to film and its mediation practices had not been dislodged. Between 2004 and 2006, FFI, which was composed mainly of longestablished figures in the film industry, handed out awards for best film and television productions. As an institution, FFI can hardly be said to have represented contemporaneous developments in the film industry. In inner circles of young film professionals who had emerged during Reform, FFI was criticized for being a bureaucratic body run in the spirit of the New Order. There was deep suspicion 
that FFI sidelined new talent in the industry and favoured the old guard and, much like New Order arisan film festivals, preferred to present awards to all participants rather than truly evaluating films (Sasono 2007). In 2006 the accumulated disappointment with FFI among young film-makers resulted in widespread controversy.

On 3 January 2007, twenty-two film-makers, actors, and professionals, mainly of the younger generation, symbolically returned the Citra trophies awarded to them between 2004 and 2006. In doing so, they protested against the jury's decision at the FFI 2006 to grant the award of Best Film to Ekskul (an abbreviation of Ekstra kurikuler (Extra-curricular, Nayato, 2006), and the jury's refusal to explain the selection process. The film Ekskul, produced by soap opera production house Indika Entertainment, was a campy highschool drama barely distinguishable from run-of-the-mill Indonesian soaps. It was inspired by the Emmy-award winning American television film Bang bang you're dead (Guy Ferland, 2002). Based on a true story, Ekskul recounts the tale of a student who takes his schoolmates hostage at gunpoint. In terms of the number of votes it received at FFI, the movie outdid the films Berbagi suami (internationally distributed under the title Love for share, Nia Dinata, 2006), a film dealing with problems of polygamy, and Denias; Senandung di atas awan (Denias; Singing above the clouds, John de Rantau, 2006), which was about a Papua farmer's son who pursues his dream to go to a real school. Both were widely acclaimed by film critics and film-makers alike (Taufiqurrahman 2007). The surprise victory of Ekskul unleashed a storm of discontent among film professionals of the film indie generation and beyond, who were exasperated by the hidebound Indonesian film industry.

Between 24 and 29 December 2006, around forty film professionals founded the new film movement MFI. Approximately 200 people, among them directors, producers, actors and actresses, film crew members, festival organizers, curators, journalists, members of film communities and organizations, and others who wanted to see changes in the Indonesian film industry supported the movement. MFI used the protest against FFI awarding a Citra for Best Film to Ekskul as the point of departure from which to criticize and call for changes in the official system in the Indonesian film industry. ${ }^{31}$ In an interview, film producer, member of MFI, and chairman

31 In a press-statement issued on 3 January 2007, the movement called attention to the fact that the film Ekskul illegally used the music score of several Hollywood films, which constituted a breach of copyright. Pointing out that this was not noticed by the FFI jury, MFI concluded that this was an indication of the poor management and lack of competence on the part of the festival organizers. 
of Jiffest Shanty Harmayn commented: 'We use this moment to call for changes to the system in our film industry. That is our main agenda' (Hari 2007). In a petition addressed to the State Minister of Culture and Tourism, the president, leaders of BP2N and other film-related organizations, and the House of Representatives on education and culture, MFI insisted that the organization of the 2006 FFI withdraw the award for Best Film and give a public explanation of the selection process used by the jury. MFI also petitioned for the temporary disbanding of FFI as well as the shutting down of all old film organizations and institutions and for replacing these with new, more democratic and more transparent equivalents. Turning to the legal side of things, MFI called for a revision of the 1992 Film Law and for a fundamental change in the rules and implementation of film censorship, as it was convinced that film should be regulated by a system of age classification rather than censorship, as was the case now. MFI vowed that if these demands were ignored, its members would boycott future state-organized festivals and consistently reject all activities organized by the government in the name of the Indonesian film industry. ${ }^{32}$

The controversy surrounding the 2006 edition of FFI exposed the tensions straining the relationship between the surviving New Order film institutions and the fresh sentiments pervading the industry espoused by newly emerging film-makers in the era of Reformasi. In 2006, the same system, institutions, and people that had been in place under the New Order still officially ran the film industry. Now, under the supervision of the Department of Culture and Tourism, old hands, mostly retired film professionals, were in charge of the BP2N film organizations. Although Reform had led to new press legislation and a new broadcast law, the film industry was still regulated by legislation dating back to 1992. As mentioned in Chapter 2, since the production of Kuldesak, in practice filmmakers had not abided by all the rules and regulations of the New Order film law. Most film-makers whose talents emerged during and after Reform no longer bothered to observe all the stages of film mediation scrupulously set out by the New Order regime, and did not subscribe to any of the official film organizations authorized by BP2N. The only New Order film institution still carrying considerable weight was LSF. When producers chose to distribute their films through official channels for film exhibition, such as cinemas or through legal VCD or DVD productions, they were required to hand in a film copy to the censor beforehand.

32 See 'Pernyataan sikap MFI', http://masyarakatfilmindonesia.wordpress.com/pernyataansikap (accessed 19-12-2011). 
The state censor institute was notorious for both its ultra-conservatism and its arbitrariness. The criteria for censorship imposed by the board were extremely blurred. ${ }^{33}$ The main explanation given for censoring a film was fear of social unrest, which meant the board was highly receptive to protests from religious groups, bureaucrats, and people in powerful positions. ${ }^{34}$ Although many believed that censorship in Indonesia was redundant given the widespread availability of pirated VCDs and DVDs and the Internet, LSF's director, Titie Said, claimed that without censorship there would be 'more damage to society' (Diani 2005). Commenting on censorship, Titie argued: 'It's not undemocratic, we're not against artistic freedom. But there is a bigger interest here, that of the nation' (Diani 2005). The gist of the protest launched by MFI against FFI was that the latter was representative of both the state film system and state support for specific narrative practices. MFI argued that the time had come to revise the New Order 1992 Film Law, the film institutions, and particularly the modus operandi of LSF.

MFI encountered both support for and opposition to its ideas. Activists and practitioners who wanted to change film legislation, members of Karyawan Film Television - Asosiasi Sineas Indonesia (KFT-ASI, Film and Television Employees - Association of Indonesian Cineasts), and even the cinema network Cinema 21 supported MFI (Imanda 2007; Adityawarman 2007). Its challenge rocked most old film organizations, which sensed that their power was being contested and which preferred to hold on to the status quo. ${ }^{35}$ Religious communities were also far from happy with the idea of reforming the film industry. Some conservative groups were particularly worried about the appeal to change the working method of the censor institute. They interpreted this as a call to abolish film censorship altogether, and accused film-makers of wanting to dis-

\footnotetext{
33 For example, in kissing scenes sometimes even a mere peck on the lips was cut. However, as mentioned earlier, the kissing scene in the teen flick Ada apa dengan Cinta and, to great surprise, a gay kissing scene in Arisan!, and even a masturbation and lesbian sex scene in the film Detik terakhir (Last second, Nanang Istiabudi, 2005), passed the censor board uncut (Diani 2005).

34 In addition to the 2004 example of Buruan cium gue!, in 2005 the censor institute withdrew the action film Bad wolves (Richard Buntario, 2005) because the police objected to the portrayal of corrupt officers in the film. The police said it would tarnish the image of the force, which, as journalist Hera Diani (2005) commented, was in fact already at an all-time low.

35 Likewise, the FFI organizers, who initially failed to comprehend the wider objective of MFI, did not see the protests as a positive effort to bring about change. In the mass media, they criticized the returning of the Citra as an act by ill-mannered youngsters who could not accept their defeat. Veteran film-maker Chaerul Umam, a member of the FFI jury who himself had won a Citra for his film Ramadhan dan Ramona (Ramadhan and Ramona) in 1992, dismissed the young film-makers as childish for staging a protest: 'It shows that they can't accept their defeat. If they thought there was a problem, they should have informed us as soon as possible' (Hari 2007).
} 
band film censorship in order to be free to produce pornographic films (Imanda 2007).

In the middle of all this commotion, FPI decided to show its support for film censorship. On 17 January 2007, an FPI delegation visited the LSF office and was given a tour which included an explanation of the work of the institute. After the tour, the leader of the delegation and secretary general of FPI, Ustaz Jafar Sidik, stated that FPI would join and monitor the work of LSF and protect it in view of the threat posed by some groups which wanted to disband it. ${ }^{36}$ Sidik was convinced that the censor institute was desperately needed: 'LSF must stay. Look at what is screened on television and in cinemas, it has been censored but is still outrageous. It would be even worse if there were no censor. In our position as a mass organization we are going to monitor this institution, and simultaneously broaden the work terrain of FPI. ${ }^{37}$ Sidik planned to hold conversations with members of the House of Representatives and the government in preparation of an appeal for the intensification and broadening of film censor criteria. He was in no doubt that films now screened in cinemas and on television contaminated the religious values and morality of the Indonesian nation. In particular, Sidik would have liked to add a ban on showing elements of mysticism to the existing criteria. In response to the visit of the FPI delegation, Titie Said commented that she had explained to FPI that the board censored films on the basis of criteria drawn from religion, politics, culture, and public order: 'LSF is a guardian of the nation's morality, protecting it from bad influences, just as FPI' ${ }^{38}$

The involvement of the Islamic pressure group FPI in supporting LSF and opposing the MFI petition revealed two separate issues. The case can be seen as representative of the wider conflict between conservative and liberal forces in their jockeying to gain the upper hand in ruling the nation. MFI's call for changes to the system in the film industry represented another bid to reform Indonesian society. LSF and FPI both represented groups which were determined to hold on to their status quo and by doing so "protect the nation's morality'. Secondly, the MFI versus LSF and FPI case provides a good example of discourses on the state's deployment of Islamic pressure groups in its bid to cling to power. Media

36 'Keberadaan sensor film didukung FPI', Bisnis Indonesia, 17-1-2007.

37 'LSF harus tetap ada. Lihat saja tayangan televisi dan bioskop, disensor aja gila, apalagi kalau lembaga sensor itu nggak ada. Selaku Ormas, kami akan memantau kelembagaan ini, sekaligus memperluas bidang kerja FPI' ('Keberadaan sensor film didukung FPI', Bisnis Indonesia, 17-1-2007; Hadysusanto 2007).

38 'LSF harus dipertahankan'. Posted on Layarkata-Network@yahoogroups.com, LayarkataNetwork, 'FPI siap melawan sineas muda?', 19-1-2007. 
watcher Veven Wardhana suggested that there was a widespread belief that the censor institute itself had actually invited FPI. Wardhana intimated that the board invited the Islamic mass organization to provide a justification and legitimization for the existence of the institute. He speculated that in all probability during the tour and the concomitant explanation of the working methods of LSF, the FPI delegation was deliberately shown sensual and violent film scenes which had been banned by the board in order to elicit FPI's response that censorship was crucial. Wardhana pins his arguments on the fact that by means of the statements made by the FPI delegation before the invited press, LSF ensured that it secured its authority on the basis of popular support. ${ }^{39}$

In addition to Veven Wardhana, film-maker and festival organizer Dimas Jayasrana also believed that FPI was used as a strategic partner by the censor institute. Just as Wardhana, Dimas suggested FPI was manipulated by the board to substantiate the fact that it had 'the voice of the people' (suara masyarakat), which supported the existence of the institute and its censorship decisions. Dimas stated that this alliance, in which FPI reinforced the position of the state-sponsored LSF, extended beyond the bounds of film. He was convinced that it was just one more example of the broader power play instituted by the state. In his view, contemporary Indonesian Islam is used as a commodity and political tool either to perpetuate or alternatively to seize power. The state manipulated FPI and other militant Islamic organizations in the same way LSF had, assisting it in its efforts to preserve the status quo and consolidate its own power. Dimas pointed out that the government had never intervened to quell any of the aggressive protests launched by FPI or any other militant Islamic groups. In fact, these groups had been fostered by the state to make sure that the atmosphere remained unstable and chaotic, which in turn supplies the state with a raison d'être. Dimas was convinced that Indonesian politics were still built on generating fear of the recurrence of political, social, and economic instability. Fear of militant Islam has now replaced the fear of communism so as to legitimate strict state control of society. If necessary, fear of radical Islam would give leeway to the state to seize all power if this were deemed essential to national security. ${ }^{40}$

39 Personal communication with Veven Wardhana via e-mail on 22 January 2007. In an interview, Titie Said denied the charge that FPI had been invited by LSF. She stated it was a visit similar to those made by many other Indonesian social communities and groups to the institute. The censor institute, she emphasized, 'always opens its door to the people' (Hadysusanto 2007). 40 Communication via e-mail with Dimas Jayasrana on 23 January 2007, and personal communication in Jakarta in March 2007. 
Other film professionals, such as directors Aria Kusumadewa and Tino Saroenggalo as well as film critic Ekky Imanjaya, have supported this point of view. ${ }^{41}$ Pursuing this line of argument and taking account of the wider notion of the state, the support of Islamic groups for the state film censor has been perceived as an example of the way in which Islam was used as a device to control Indonesian society. ${ }^{42}$

\section{CONCLUSION}

In both post-Soeharto audio-visual media and Indonesian politics there has been a perceptible growth in representations of Islam. However, the fact that Islam has been garnering a large amount of publicity does not mean that it has actually gained in terms of political clout. Instead, Islam is but one part of a complex discourse about the organization, principles, and representation of the postSoeharto Indonesian nation. The two specific cases of Buruan cium gue! and of MFI versus LSF/FPI have revealed debates about what social norms, religious beliefs, and realities are acceptable in narrative practices in post-Soeharto Indonesian audio- visual media. These debates have certainly been tied into the endeavours by some Islamic groups to implement national moral codes based on the application of Islamic principles in society. Moreover, they have clearly revealed the divide between conservative and liberal forces in their efforts to rule the nation.

In his study on the historiography of modern nationalism in East Asia, the historian Prasenjit Duara has called attention to the different 'nation views' which nationalism in each nation encompasses. As Duara argues, nationalism as an ideology and politics are neither uniform nor monolithic. Such different groups as political parties, women, workers, farmers, the majorities as well as the minorities in a nation-state have different conceptions of the nation, for which Duara has coined the term 'nation views'. Different nation views moreover compete to define the 'authentic' history and traditions - regimes of authenticity - of the people of a nation-state. Generally speaking, it is the state which directs and determines which regimes

41 Personal communication with Aria, Ekky and Tino in Jakarta in March 2007. Moreover, they pointed out rumours which insinuated that FPI was an organization run by Governor of Jakarta Sutiyoso, or the police forces.

42 For more on the utilization of the threat of Islamic fundamentalism in Muslim countries to justify repressive state measures, see Esposito 1999:172. 
of authenticity will form the foundation of the nation. However, at many points non- state movements and the force of their ideas test and transform the structure of the regimes of authenticity and the nation-state (Duara 2008). The debate about filmic moral bounds that I described above can be seen as part of a process in which multiple nationalisms test the structure of the nation. To the filmmakers who joined MFI, democratic rights-based individualism and freedom of expression overrule moral bounds determined by religious nation views. To the religious groups, Islam represents the basis of the Indonesian nation and identity, and this foundation should direct the content of domestic film and television. Secular images and representations are discarded and shrugged off as influences of foreign culture and propaganda.

Muhamad Ali's reading of the controversy about the Pornography Bill, which took place in the interval between the Buruan cium gue! furore and the MFI versus LSF/FPI clash, offers a constructive analysis of the context in which these different nation views surfaced. Ali has suggested that the anti-pornography controversy is best understood in the context of power relations. In his opinion the controversy reveals a power struggle about the definition of what forms a morally upright society in the context of the Indonesian nation-state. The struggle about what constitutes public morality, he argues, addresses the questions of which views, practices, and traditions should be maintained in Indonesian society, and which should be discontinued. It also sheds light on the matter of how to deal with religious beliefs and social norms and how to relate these to the state. Ali thinks that this power struggle has been greatly influenced by the fact that the post-Soeharto definition of an Indonesian nation-state has never been formulated in unequivocal terms. In his words: 'Within the context of an ambiguous definition of an Indonesian nation-state, pressure groups continuously want to move the pendulum toward a nation based on religious dogma' (Ali 2006).

Being rooted in different 'regimes of authenticity', the opposition of secular and religious groups in the two cases of Buruan cium gue! and MFI versus LSF/FPI also exposed the divide between the secular and religious conceptions of daily reality. In a Foucauldian sense - each society causes certain types of discourse to function as true - the claim by Raam Punjabi that his film merely represented social reality as opposed to AA Gym's argument that it encouraged immoral behaviour at odds with Indonesian religious values and culture, exposed a power struggle over the 'true' representations of Indonesian realities. Nevertheless, the fact that AA Gym won the controversy over Buruan cium gue! cannot be perceived as a victory 
of religious authority over secular Indonesian nation views and realities. Instead, as such cultural commentators as Prananto have put forward, it was a victory of stardom: the most popular celebrity of the moment rules the nation, in this case the widely celebrated celebrity-kyai AA Gym.

In the struggle to define the representations and realities of contemporary Indonesian society, to a large extent Islam as a religion has taken centre stage in the debates. Islam was increasingly transformed into a commodity; not only as part of the framework of Ramadan, as discussed in Chapter 4, but also in the new television genre of religious soaps, which proved just as adept at using the outward appearances of Islam to attract viewers. Ironically, and in a way similar to the narrative practices employed to address Islam under the New Order, religious soaps have waved the banner of Islam to depict all sorts of controversial social norms or realities and still escape unscathed. In other words, television producers have juggled with images of Islam to sell their productions and to safeguard these from protests. In the same vein, Islam has been progressively used as a political tool. The government, political parties, and mass organizations have not hesitated to invoke the spectre of Islam in their play for power. Moreover, according to some film-makers the state has fuelled a fear of domination by extremist Islam to guard the status quo. The cases of Buruan cium gue!, LSF and FPI versus MFI, and 'religious soaps' show how Islam has been used by Indonesian film and television producers as well as groups active in the socio-political field to acquire assets and power. In this context, the rise of Islam in the post-Soeharto audio-visual media and in Indonesian society can be understood as a tactic employed by different parties to use this religion as an instrument to try to have it their way. 